\title{
Assessment of Challenges and Opportunities of Wetlands Management in Bule Hora Woreda, Borena Zone, Southern Ethiopia
}

\author{
Adugna Babu*
}

Department of Natural Resources Management, Bule Hora University, P.O. Box: 144, Bule Hora, Ethiopia

\begin{tabular}{|c|c|}
\hline Abstract & Article Information \\
\hline $\begin{array}{l}\text { The objective of this study was to assess the status and challenges of wetlands } \\
\text { management in Bule Hora Woreda so as to enhance the sustainability of the wetlands to } \\
\text { increase the advantages of wetland beneficiaries and ecological health. Results of the } \\
\text { study Indicates that, Bule Hora woreda has many wetlands, which they use for different } \\
\text { purposes including for grazing, for traditional house making, for fresh water supply, for } \\
\text { cultivation of some crops and for other purposes. However, the areal coverage, their } \\
\text { distribution, their benefits, as well as their management practices are not studied in the } \\
\text { Woreda. According to this study, some of the degrading factors of these wetlands include } \\
\text { unplanned settlement, eucalyptus plantation, deforestation, agricultural practices, } \\
\text { overgrazing and gold extraction particularly for Rophi Megada wetlands. In addition, to } \\
\text { describe the trend of change of these wetlands Landsat TM 1986, Landsat ETM } 2000 \text { and } \\
\text { SPOT } 2006 \text { were used to show the declining pattern of these resources. As a result of the } \\
\text { degradation of these resources many local communities experienced with scarcity of } \\
\text { some of their basic livelihood such as scarcity of fresh water supply, scarcity of some } \\
\text { crops as well as some important edible plants like Carissa spinarum L. (Apocynaceae), } \\
\text { Syzygium guineense var. (Wild.) DC. (Myrtaceae), Dioscorea bulbifera L. (Dioscoreaceae), } \\
\text { Olea europaea subsp. cuspidata (Wall. Ex G. Don) Cif., (Oleaceae) and others. } \\
\text { Furthermore, due to the degradation of these wetlands, many wetland dependent species } \\
\text { were disappeared. The information gathered from elders also revealed that some wildlife } \\
\text { species such as duicker, aardvark, porcupine, bushback, Trign (Civettictis civetta), Rabbit, } \\
\text { and pig are under threat due to the destruction of these resources. Some bird species like } \\
\text { Cattle Egret, Great White Egret, Hadada Ibis, Egyptian Goose, Egyptian Vultur, Abyssinian } \\
\text { Ground Hornbill, and Laughing Dove are also disappeared from these wetlands. } \\
\text { Copyright@2015 STAR Journal, Wollega University. All Rights Reserved. }\end{array}$ & $\begin{array}{l}\text { Article History: } \\
\text { Received : 03-04-2015 } \\
\text { Revised : 14-06-2015 } \\
\text { Accepted : 27-06-2015 } \\
\text { Keywords: } \\
\text { Wetlands } \\
\text { Bule Hora } \\
\text { Unplanned settlement } \\
\text { Eucalyptus plantation } \\
\text { Deforestation } \\
\text { Agricultural practices } \\
\text { Overgrazing } \\
\text { Gold extraction } \\
{ }^{*} \text { Corresponding Author: } \\
\text { Adugna Babu } \\
\text { E-mail: } \\
\text { adugna.tirunesh@gmail.com }\end{array}$ \\
\hline
\end{tabular}

\section{INTRODUCTION}

Wetlands are among the world's most productive environments. They are cradles of biological diversity, providing the water and primary productivity upon which countless species of plants and animals depend for survival. They support high concentrations of birds, mammals, reptiles, amphibians, fish and invertebrate species. Wetlands are also important storehouses of plant genetic material (Ramsar Convention Secretariat, 2006). The definition of wetlands varies from country to country. There is no agreement to give the exact definition of wetlands. The most common definition for wetlands at International level is given by the Ramsar Convention. According to the Ramsar Convention Secretariat (2006), wetlands are defined as: "areas of marsh, fen, peatland or water, whether natural or artificial, permanent or temporary, with water that is static or flowing, fresh, brackish or salt, including areas of marine water the depth of which at low tide does not exceed six metres". Wetlands are areas where water is the primary factor controlling the environment and the associated plant and animal life. They occur where the water table is at or near the surface of the land, or where the land is covered by shallow water.
Wetlands are becoming increasingly recognized as important natural resources in developing countries because of their ability to fulfill a range of environmental functions and produce a number of products that are socially and economically beneficial to communities. Wetlands are vital natural resources, both in terms of their environmental functions and their products, which are used extensively by people (Dixon and Wood, 2003). They are amongst the world's most productive environments and provide a wide array of benefits (Barbier et al., 1997, Ramsar Convention Secretariat, 2006). The interactions of physical, biological and chemical components of a wetland, such as soils, water, plants and animals, enable the wetland to perform many vital ecological functions, like water storage; storm protection and flood mitigation; shoreline stabilization and erosion control; groundwater recharge; groundwater discharge; water purification; retention of nutrients; retention of sediments; retention of pollutants; stabilization of local climate conditions, particularly rainfall and temperature. Wetlands also frequently provide tremendous economic benefits, such as water supply (quantity and quality); fisheries; agriculture, timber 


\section{Adugna Babu}

production; dry season grazing through the maintenance of water tables and nutrient retention in floodplains; building materials; firewood, income generating activities, energy resources; wildlife resources; and a wide range of other benefits, including herbal medicines; recreation, tourism and cultural opportunities (Emerton, 1998; Millennium Ecosystem Assessment, 2005). Direct harvest of wetland resources yields various important benefits to satisfy human basic materials (Choowaew, 2007).

According to Millennium Ecosystem Assessment (2005), despite their advantages; currently the degradation and loss of wetlands worldwide is more rapid than that of other ecosystems. Similarly, the status of both freshwater and coastal wetland species is deteriorating faster than those of other ecosystems. The primary indirect drivers of degradation and loss of inland and coastal wetlands have been population growth and increasing economic development. The primary direct drivers of degradation and loss include infrastructure development, land conversion, water withdrawal, overgrazing, pollution, overharvesting and overexploitation, and the introduction of invasive alien species. Clearing and drainage, often for agricultural expansion, and increased withdrawal of fresh water are the main reasons for the loss and degradation of inland wetlands such as swamps, marshes, rivers, and associated floodplain water bodies (Jones, 1997).

Wetland resources in Ethiopia are not fully documented. They are currently threatened throughout Ethiopia (McKee, 2007). Draining of wetlands for agricultural purpose is a century old practice in some parts of the country, mainly in Southwest Ethiopia. However, improper draining mechanisms, double cropping, growing of perennial crops such as sugar cane within wetlands ecosystem have become major threats for the survival of wetlands. Throughout Ethiopia, past and present wetlands areas have been and still are important sites for livestock grazing. Specifically, wetlands are often a last destination for pastoralists during the dry season in most parts of the country. However, livestock population increases, fodder shortages and the simultaneous expansion of agricultural activities have contributed to exacerbating the grazing pressure on wetlands. The pressure from grazing has resulted in changes of the wetland characteristics (Mckee, 2007). Over-exploitation or harvest of wetland resources is now a major threat in several wetland areas of Ethiopia. Excessive exploitation of resources can also lead in some cases to a direct collapse of the wetland itself.

Deforestation and losses of vegetation within a wetland catchment area is the starting cause for an accumulation of silt within the wetland ecosystem. The accumulation of silt within the wetland usually leads to a complete change in the ecosystem, resulting in biodiversity alteration, in decreases in the water holding capacity of the wetland and in the worst case in the collapse of the wetland itself (Lemlem, 2003; McKee, 2007).

Urbanization, settlement, pollution from urban centers and industrialization are also the main triggers of wetland ecosystem changes. Due to the abundance of natural resources in wetlands, many urban centres in Ethiopia are located near or in their vicinity (Bahir Dar, Awassa, Alemaya, Debrezeit, etc). However, through time and
Sci. Technol. Arts Res. J., April-June 2015, 4(2): 99-111

population increases, these urban centres or settlements have become an important source of pollution and are threatening the stability of these ecosystems (Lemlem, 2003).

In Ethiopia, wetland management is not efficiently coordinated and lacks adequate policy support. Due to the absence of workable institutional arrangement and wetland management policy, sustainable management of wetland and capacity building are not strengthened. As a result the field suffers from shortage of skilled manpower which is capable of disseminating the concept of wise use of wetlands (Shewaye, 2008). People use recklessly only with the objective of obtaining immediate benefits such as draining for agriculture, overgrazing, excessive resource exploitation, growing destructive plants such as eucalyptus and so on.

The Bule Hora woreda, one of the woredas of Borena Zone, has many wetlands in its different agroecolgical zones. No study was done regarding the distribution, contribution, their percentage of land cover, their management and factors of degradation in the woreda .These wetlands are found in the form of swamps, marshy, flood plain and rivers. Majority of these wetlands are flood plain wetlands which are characterized by flood during rainy season and dry up during winter season. The local communities use the wetlands mostly for livestock grazing particularly during dry season of the year when there is shortage of fodder.

The overall objective of this study was to assess the status and challenges of wetlands management in Bule Hora Woreda so as to enhance the sustainability of the wetlands to increase the advantages of wetland beneficiaries and ecological health. The specific objectives these studies are to assess the indigenous knowledge and local management practices of wetland management in Bule Hora woreda, to identify the socioeconomic factors leading to wetland ecosystem changes, to evaluate the consequences of wetland changes on local socio-economic conditions and biodiversity and to propose effective management strategies which is socioeconomically and ecologically sound towards sustainable management of the wetlands

\section{MATERIALS AND METHODS}

\section{Study Area}

Bule Hora Woreda is one of the fifteen woredas of Borena Zone, and is bordered by the Gedeb Woreda of Gedeo zone in North, in south by the Duda Dawa in East by Melka Soda Woreda and in West by Amaro Woreda and Burji people of southern Nations (Figure 1). The woreda has a distance of $470 \mathrm{~km}$ from the capital city of the country. The woredas has 45 rural kebeles and 3 town kebeles (AOBHW, 2013).

\section{Crop Production}

According to the Agricultural Office of the Bule Hora Woreda, (2013), some of the dominant crops that are produced in the woreda include maize, teff, barley, wheat soybean and beans. These crops are used for home consumption. The woreda also produces some cash crops such as coffee, chat, inset and different varieties of fruits. 


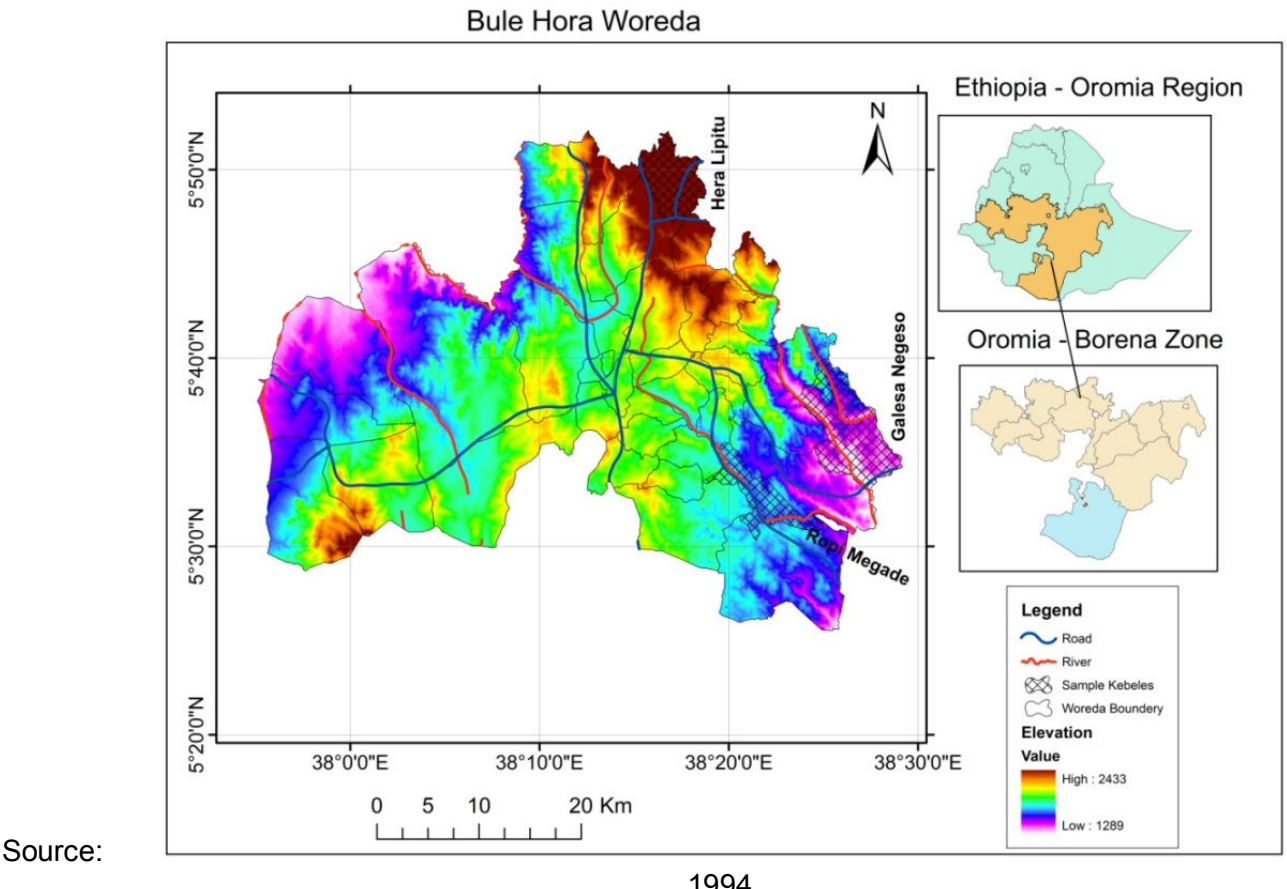

Ethio-GIS,

Figure 1: Location map of the Study area

\section{Relief, Drainage and Climate}

Relief: Bule Hora is a district with varying elevation. The topography of the woreda is known by its undulating area, plain, mountain, valley and low plateaus. The existing mountain is kegna.

Drainage: The woreda has a drainage system characterized by perennial and seasonal rivers. The perennial rivers include Afalata which flows along the border of Dugda Dawa District. The other one is Galana river and drains from the Galana Metari kebele.

Climate: The district has only three types of agro Climatic or traditional thermal zones. These are the bada dare (Wayina dega), Bada "dega" and Gamojii (kola). About $55 \%$ of the total area of the district falls under Bada dare. The remaining 11 and $34 \%$ falls under Bada \& Gamoji respectively Agro- climatic condition. The woreda has an average maximum temperature of 30 and $15{ }^{\circ} \mathrm{C}$ is the minimum average temperature.

\section{Major Rainy Season}

Bule Hora has two major rainy seasons namely Arfasa and Ganna. Arfasa is the major crop season especially for cultivation of field crops. It begins from march 15 and ends on may 15 the second rainy season Ganna in which only a few cereal crops are grown begins from September 15 and ends in November 15.

\section{Soil}

According to the soil map of Borena zone, the soil unit of Bule Hora woreda are Black, Red brown and grey. Of these, the first two are the types of soils covering the largest part of the woreda. Red soils are young soils developed in recent alluvial deposits and generally good for agriculture. The major types of soil in the district are Black, Red, Brown, and Grey. The spatial coverage of these soils is exactly unknown because all types of soils are found over the total area of the district. However, recent information from Agricultural and rural development office reveals that the percentage coverage of the soil approaches the following (Red $45 \%$, Brown 22\%, Grey $17 \%$, Black $13 \%$ and Others $3 \%$ )

\section{Demogrophic Information}

Population of Bule Hora Woreda belongs at most to five ethnic groups: namely Guji oromo, Burji, Amara,Gurage and koira. According to the current Housing and census data appointed the total population of Bule Hora woreda is 266,150 of which 134,603 and 131,547 is male and female respectively (AOBHW, 2013). The rural settlement pattern is more of scattered and even in some places of the 'kola ' area no constant settlement pattern. However, a few farmers are seen settled at areas where social service like market and the like are situated and this created rural village.

\section{MATERIALS AND METHODS}

\section{Research Design}

Both quantitative and qualitative data (the mixed approach) were used as they are pertaining to the benefits, threats and management of the wetlands. In this case, sequential exploratory strategy was implemented. The initial phase of the design dealt with qualitative data collection and analysis which was supported by quantitative data collection and analysis. However, priority was given to the qualitative aspect of the study. This is because; most of the data that were gathered from the study area are qualitative in nature.

\section{Sampling Method}

Among the many wetlands found in the Bule Hora Woreda, three wetland areas; namely Rophi Megada, Galessa Negesso, and Hera Liphitu were purposively selected based on their accessibility. As criteria, it is essential to select the kebeles who mostly use wetlands .Therefore, 90 households, i.e., 30 households from each kebele living around the wetlands were purposively 


\section{Adugna Babu}

selected to identify the local management practices and threats to the wetlands and evaluate the impact of wetland changes on local socio-economic conditions and ecological health, particularly on biodiversity.

\section{Data Collection Methods}

\section{Primary Data Collection Methods}

The primary for this study was gathered through Questionnaires, Field Observation, Focus Group discussion, and Key informant interview to investigate the causes of wetlands degradation, their consequences and their management practices in the study areas.

Collection of Biological Data: Wetlands are crucial sources of biological diversity. The dominant plant species of the wetlands (hydrophytes), which are under threat, were identified by botanist on the field. Again, some of the common wildlife and bird species existed in these wetlands were also specified by the local elders.

\section{Secondary Data Collection}

The secondary data sources used in this study include related documents, studies, and other useful written materials needed for the study from internet sources, study reports, survey reports and other significant published papers to identify the drivers of the wetlands degradation due to socio- economic factors, and impacts of wetlands loss on economic conditions and biological species, especially on fauna and flora resources. Furthermore, Satellite images of the study area were used to analyze the trends of changes of the wetlands. Landsat TM (Thematic Map) 1986, Landsat ETM (Enhanced Thematic Map) 2000 and SPOT (System Pour 1'Observation de la Terre) 2006 were obtained from the Ethiopian Mapping Agency. Furthermore, using ERDAS (Earth Resources Data Analysis System) 8.6 software, the trend of changes of the three wetlands were also identified.

\section{Data Analysis}

Both quantitative and qualitative (the mixed approach) analytical methods were implemented in this study. Furthermore, the qualitative data that were gathered through interviews, focus group discussion, key informant interview, and field observation were analyzed using content analysis by describing and interpreting the situation deeply and contextually, so that the real driving factors of the wetlands degradation, their impact on rural livelihoods and biological species and the management status of the wetlands were assessed.

\section{RESULTS AND DISCUSSION}

\section{Indigenous Wetlands Management}

Locally developed institutions that include rules and regulations, common values and mechanisms of conflict resolution are increasingly regarded as adaptive solutions to resource management problems at the grass -roots level. Since they are rooted in community social capital rather in external, top-down decision making ,they are seen as being dynamic ,flexible and responsive to societal and environmental change and, as such, they promote sustainability (Dixon and Wood, 2003). In the same, the Borena zone has long history of traditional institution called "the Gada System" which is well structured and organized to solve conflicts and environmental problems particularly conservation of resources. According to the information gathered from
Sci. Technol. Arts Res. J., April-June 2015, 4(2): 99-111

the study area, this traditional enforces the local communities not to degrade the different natural resources through giving counseling services. The leader of "the Gada System" gather the local communities from time to time and propose the resource management strategies. They also punish someone who clears trees from the communal land. Even someone who clears trees from his/her own land can be considered as 'greedy' and has low social status by others. However, traditionally, in the study areas, no more attention is given for the management of wetland resources. But, the management practices that they make for forests are indirectly the management for the wetlands.

When we consider the management of natural resources based on the information gathered from the study areas, control of catchment deforestation is one of the management aspects of such resources. Because, deforestation increases runoff and change the hydrological character of wetlands. To sum up, they mentioned plantation of plants that have an adverse impact on wetlands is also forbidden according to the traditional resource conservation strategy set by selected local leaders. But, these practices are failed to be implemented at all due to the concept of resource ownership especially privately. Planting of eucalyptus close to wetland springs are common and have adverse impacts by absorbing water from the ground and thereby leading to shrinkage of these resources. Fencing areas around the wetlands is also common by the local communities of the study areas. The information gathered from the local people revealed that fencing takes place for many purposes for instance to protect the wetlands from human and animal feet which may cause compaction.

It is also done for the purposes of wetland products which can be harvested for sales (grass, reeds, and Cyprus latifolius) and construction of traditional houses for residential in rural areas. Wetlands are also fenced for the purposes of seedlings of coffee and some other vegetation.

However, there is different management practices of wetlands by taking in to account whether these resources are either communally owned or privately owned. That means, property ownership plays paramount roles in effective resource management. Depending on the survey result, most wetlands of study areas are communally owned and used as communal grazing land and no more attention for management practices has been made .In contrast, only small size of these wetlands are in the hand of some farmers and are conserved to some extent as compared with that of communal.

\section{Socio-Economic Causes of Wetlands Degradation}

Wetland degradation refers to the decline in the ability of wetlands to fulfill the various wetland functions which have achieved in the past, especially when in their natural condition (Afework et al., 2000). In particular, wetland degradation is typified by the loss of moisture and the drying out of wetlands. This will lead to changes in the vegetation, such as the loss of cheffe (Cyprus latifolius), the natural wetland vegetation in most wetlands and the invasion by dry land species, which are typically seen as weeds. According to Emerton et al. (1998), the water, soils, plants, hydrological and ecological characteristics of wetland directly support economic activities. These economic activities are those which are based on wetland 


\section{Adugna Babu}

resources and those which depend on wetland services (Dixon and Wood, 2003; Dixon and Wood, 2007). Wetland supports farming because it provides the water required for irrigated crop cultivation, as well as depositing sediments and nutrients, which maintain soil fertility. They are also used for fishing, and livestock grazing. They supply families with basic needs such as water, construction material, and fuel (Tejuoso, 2006). In the study areas, however, despite their unwise uses and low attention for management ,these resources are under severe threat.

According to the woreda informants, the management of the wetlands is not commonly known in isolation from other natural resources. Rather they practice conservation of some resources such as forests, soils and water resources based on the designed policy of our country. Training concentrated on wetlands management as well as guidelines for management are not provided at different levels. Due to the above facts, there is no documentation of these resources. The exact area coverage of wetlands of the woreda is also not well known. Generally, little management practices are made indirectly for wetlands in relation to water resources management in the woreda. The information gathered from the woreda agricultural office also revealed tha there is no policy regarding wetland management practices independently. Besides the above ideas, they confirm that there is no policy which directly highlights wetland conservation and planning.

According to Mellese, (2008), wetlands did not get the attention that commensurate the services they provide. The country's essential documents from the Constitution to the strategic documents, rarely dealt with the issue of wetlands.

On the other hand, these documents have duly considered the protection, development and wise utilization of natural resources, which definitely incorporate wetlands. Moreover, some policy and legal documents tried to treat wetlands scantly. The informant of the study confirmed that due attention are not given for

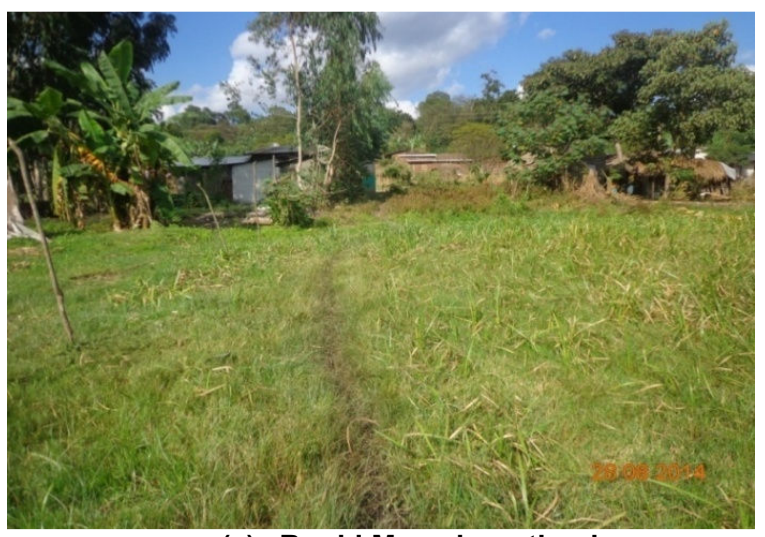

(a) Rophi Megada wetland
Sci. Technol. Arts Res. J., April-June 2015, 4(2): 99-111

wetlands in their local area and these wetlands are not considered as valuable natural resources and are referred to be non valuable resources due to lack of ignorance about what wetlands are; their economic and ecological contribution. According to the information gathered from field observation in addition to questionnaires the wetlands of the three study areas are under severe degradation imposed by unplanned settlement, deforestation, eucalyptus plantation, agricultural practices, overgrazing by large number of livestock.

\section{Unplanned Settlement}

Dramatic increase in human population over the years and the lucrative return from investment in and around wetland ecosystem is becoming a major driving force towards wetland degradation in different parts of Ethiopia (Forum for Environment, 2007).

As it was identified by Lemlem, (2003), human settlement is amongst the most serious problems of wetlands. For example, in Ethiopia, wetlands found around the fast-growing cities of Ziway, Awassa and Arbaminch are all under threat due to settlement. Due to the abundance of natural resources in wetlands, many urban centres in Ethiopia are located near or in their vicinity (Bahir Dar, Awassa, Alemaya, Debrezeit, etc). However, through time and population increases, these urban centres or settlements have become an important source of pollution and are threatening the stability of these ecosystems (Mckee, 2007).

According to field observation, these three wetland areas; namely Rophi Megada, Hera Liphitu and Galessa Negesso are reserved by human settlement due to scarcity of farmland (Figure 2). These wetlands are fragmented among young household population who are recently married and do not have sample of land even for resident and cultivation. To sum up , in some places of these wetlands the local communities dig ditches in wetlands in order remove the water stored in the soil so as to make home after the areas are dried well.

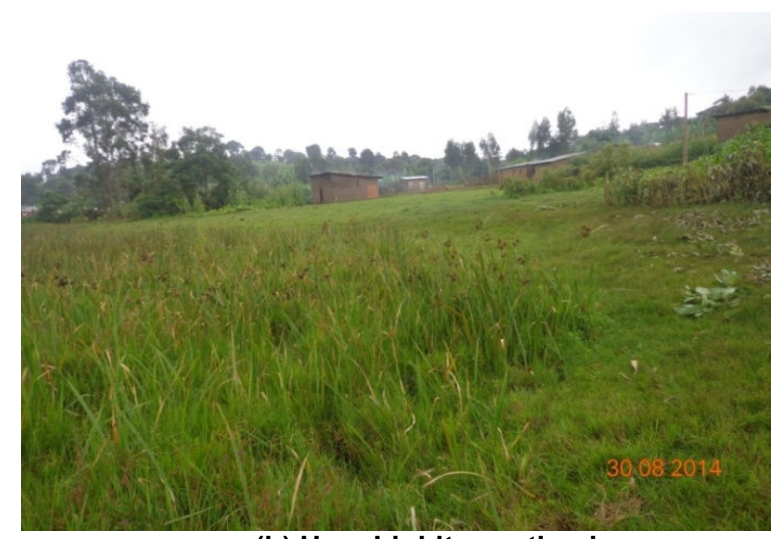

(b) Hera Liphitu wetland

Figure 2: Encroachment of wetlands by settlement

\section{Deforestation}

Deforestation has serious effects on wetlands (EWNRA, 2003). The causes of the wetlands degradation are generally the same for all of Ethiopia's catchments. The major ones are deforestation mainly for agricultural purposes, encroachment and settlement as a result of population pressure and the need for grazing land (Leykun, 2003).

Deforestation in the catchment areas of wetlands also represents a significant threat to wetland survival. Deforestation induces increased runoff and flash flooding 


\section{Adugna Babu}

in the catchment area, hence bringing a shorter residence time for water in the wetland and a reduction in groundwater recharge. The absence of forest cover on the uplands may also contribute to a movement of people into wetlands, where alternative subsistence strategies can be pursued (Forum for Environment, 2007). As it was explained by the respondents of the study area, deforestation is currently common in these wetlands mainly for construction (timber production), fuel wood, catchment cultivation, and seedling and/or nursery plantation as well as for other purposes. Some important trees such as Ficus ovate, Ficus sur, Euphorbia ampliphylla, Maesa lanceolata, Maytenus addat, Lippia adoensis, Teclea nobilis, Syzygium guineense, Senna petersiana, Vernonia amygdalina, Vernonia auriculifera, Vernonia leopoldi, Ekebergia capensis, Croton macrostachyus, Erythrina brucei, and Cordia africana are under unprecedented threat .The Ethiopian wetlands are under continual threat from deforestation due to population growth and the associated expansion of farming, increasing demand for fuel, construction wood and charcoal. Charcoal production is becoming a serious cause for concern (Lemlem, 2003).

Further, deforestation within a wetland catchment will be a starting point for accumulation of silt within a wetland ecosystem. Loss of vegetation within the catchment will result in accelerated soil erosion and consequently will lead to land degradation, which in general is a major cause for an accumulation of silt within the wetland (Tejuoso, 2006;Forum for Environment, 2007). The accumulation of silt within the wetland will lead to a complete change in the wetland ecosystem. It might result in a complete change in the biodiversity, affect the water holding capacity of the wetland, and in the worst cases, cause a collapse of the wetland itself. As it was identified during field observation these wetlands which are more prone to deforestation problems are wetlands which are communally owned. As informants explained these
Sci. Technol. Arts Res. J., April-June 2015, 4(2): 99-111

problems mostly arise from population pressure. As the size of the population grows, people are compelled to clear land for agricultural activities to ensure their survival in conditions where alternative means of existence and agricultural innovation are limited. Recently, much of the forest covers around are burned. As the vegetation cover of catchments declines, nutrient and sediment loads increase and, at least theoretically, alter the chemical and physical features of wetlands (Zerihun, 2003).

In the same way, the clearing of different vegetation around the wetlands causes the collection of sediments in to wetlands from surface runoff which leads to the burying of wetlands' water table and important vegetation resources characterizing wetlands.

\section{Eucalyptus Plantation in and around the Wetlands}

Eucalyptus plantation is also one of the crucial human induced factors contributing to the shrinkage of wetlands. Plantation of eucalyptus in wetlands is identified as a threat for the survival of wetlands. There is a strong opinion among farmers that these types of plantings on the edges of wetlands result in the systematic drying -out of the wetlands (Afework, 2008). As the respondents said, eucalyptus are planted in the wetlands for further expansion of settlement, grazing area, as well as crossing feet road (Figure 3).

Accordingly, mostly during rainy season of the year in some areas, the water table of the wetlands increase in volume and humans and animals cannot move freely in these wetlands to harvest some resources and to graze the fresh grass species respectively. To avoid such conditions they plant these trees to get accessibility and to move freely by drying the wetlands using these exotic trees. Generally, as it was understood from field observation this exotic species planted in and around the wetlands absorbed the water of the wetlands and some small springs are shrinked and dried out.

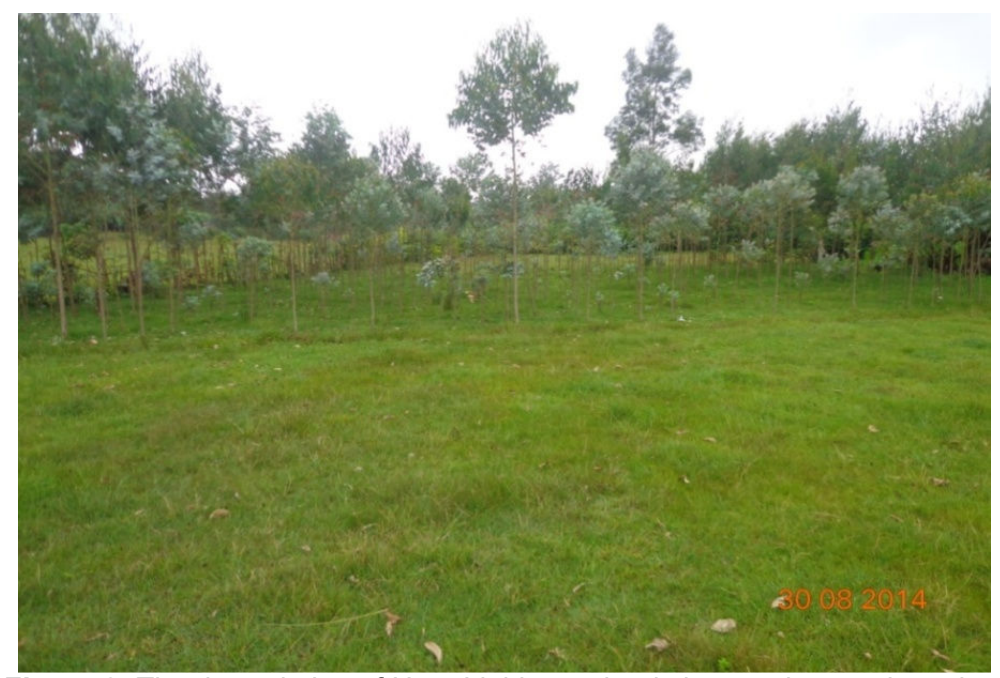

Figure 2: The degradation of Hera Liphitu wetlands by eucalyptus plantation

\section{Agricultural Practices}

Wetlands are presently faced serious ecological problems due to deleterious anthropogenic activities in the catchment. The construction of irrigation and drainage systems, clearing of forest, double cropping and use of fertilizers, herbicides and pesticides all contribute towards the damage of these indispensable ecosystems (Zerihun, 2003).

As the respondents confirmed cultivation within the wetlands mostly during the dry season are common. Cultivation of some crops such as dry season maize, 


\section{Adugna Babu}

haricot bean (phaseolus vulgaris), potato, cabbage, tomato, and sugarcane are prominent within the study areas. Each and every farmer of the local communities use their own wetlands as small nursery site particularly for plantation of different seedlings such as coffee, Giravellia rebosta, tid, Cordia africana, and some fruits like avocado, mango and, papaya either for plantation on their own farmland or for selling to other people (Fig 4).

As it was concluded by Dereje, (2008), inappropriate agricultural activities in the catchment and cultivation of buffering zones have adversely affected wetland ecosystems. It is clear that catchment degradation and cultivation of wetland buffering zones enhance the rate of soil erosion and aggravate the discharge of pesticides,

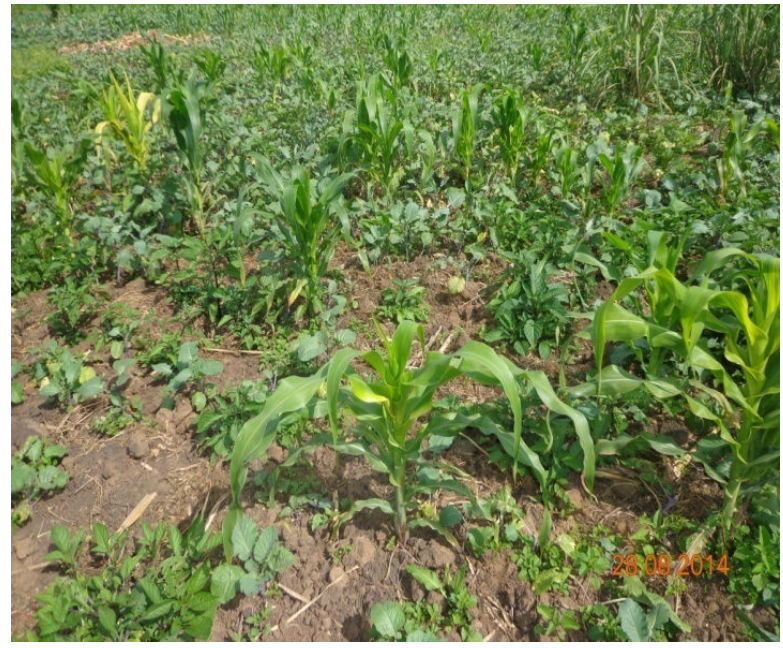

Sci. Technol. Arts Res. J., April-June 2015, 4(2): 99-111

herbicides, agricultural runoff and sediments into the wetland and thereby affects its ecological integrity and reduces the various services of wetlands. This problem also takes place in the wetlands of the study area for further agricultural expansion imposed by rapid population rate. Runoff from surrounding agricultural areas are moved and piled in to wetlands due to clearing of trees and vegetations by the local communities. As trees are cleared, the wetlands are prone to agricultural activities and diverted through digging some ditches to take the water from wetlands to other areas for further cultivation. The other problems of the wetlands pertaining to cultivation is double cropping and intermixed cropping which further degrade the ecology of these wetlands

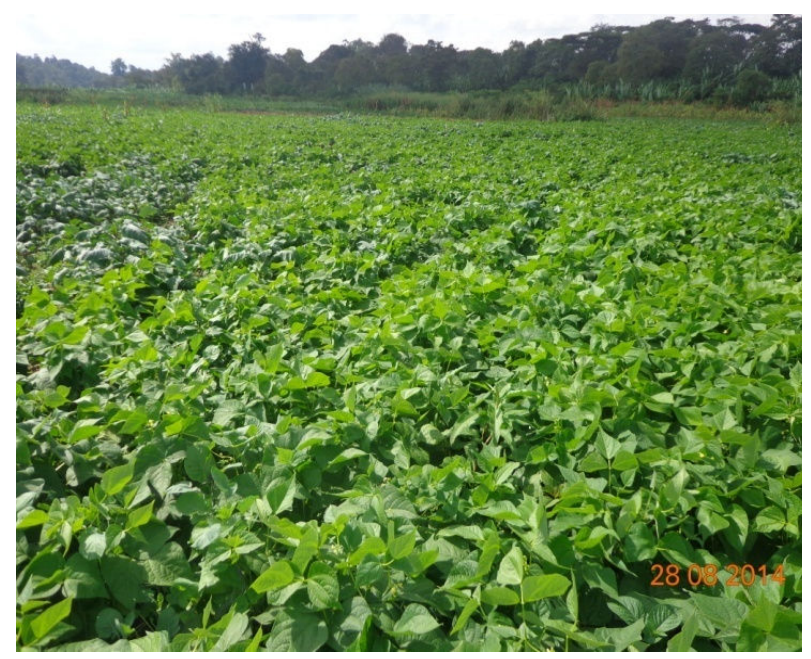

Figure 3:The degradation of Rophi Megada wetlands by cultivation

\section{Overgrazing}

According to Afework, (2008), Grazing by domestic stock is another threat to wetlands and when grazing is continuous wetlands become easily degraded and lose their natural characteristics. Throughout Ethiopia, past and present wetlands areas have been and still are important sites for livestock grazing. In the study areas, due to the perception of these wetlands as communal grazing land, large number of stock daily graze on these wetlands. Due to this factor these ecosystems are degraded and changed to bareland. According to the respondents, farmers have no awareness regarding the management; rather they compete one another for grazing mostly during dry season (Figure 5).
Specifically, wetlands are often a last destination for pastoralists during the dry season in most parts of the country. However, livestock population increases, fodder shortages and the simultaneous expansion of agricultural activities have contributed to exacerbating the grazing pressure on wetlands. In some cases, wetlands have been transformed into rough grazing land. Over grazing in wetlands can become a threat when for instance year round grazing excludes ecological recovery period of the wetland. Compaction of the wetland by livestock is also known to have a significant impact on the infiltration capacity of the soil hence affecting the hydrological system and balance of the wetland itself (Afework, 2004 cited in McKee, 2007).

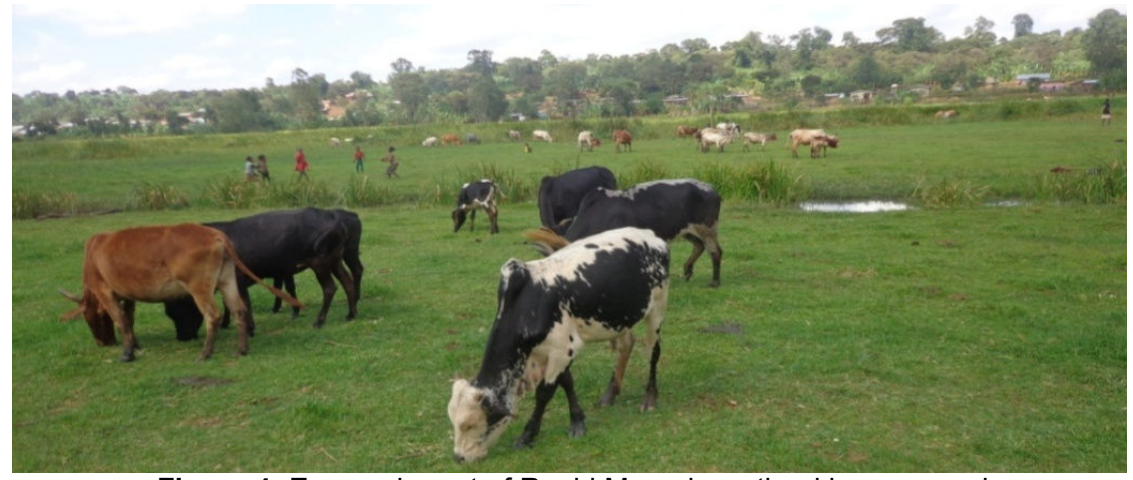

Figure 4: Encroachment of Rophi Megada wetland by overgrazing 


\section{Adugna Babu}

\section{Gold Extraction}

All the wetlands under investigation have the similar problems. But what makes the problems a little bit difference is that exposition of the Rophi Megada wetland to severe threat from gold mining. The element of gold was recently discovered in and around Rophi Megada wetland by geologists in Bule Hora Woreda in 2014. Since then the mining activities was illegally launched by
Sci. Technol. Arts Res. J., April-June 2015, 4(2): 99-111

the local communities living in and around the wetland. As some informants said the average daily income of daily laborers engaged in this activity is estimated to be 700 ETB. This is severe threat to the wetland by destroying some of the vegetation of the wetland and filling up of the wetlands by sediment is also the crucial problem (Figure $6)$.

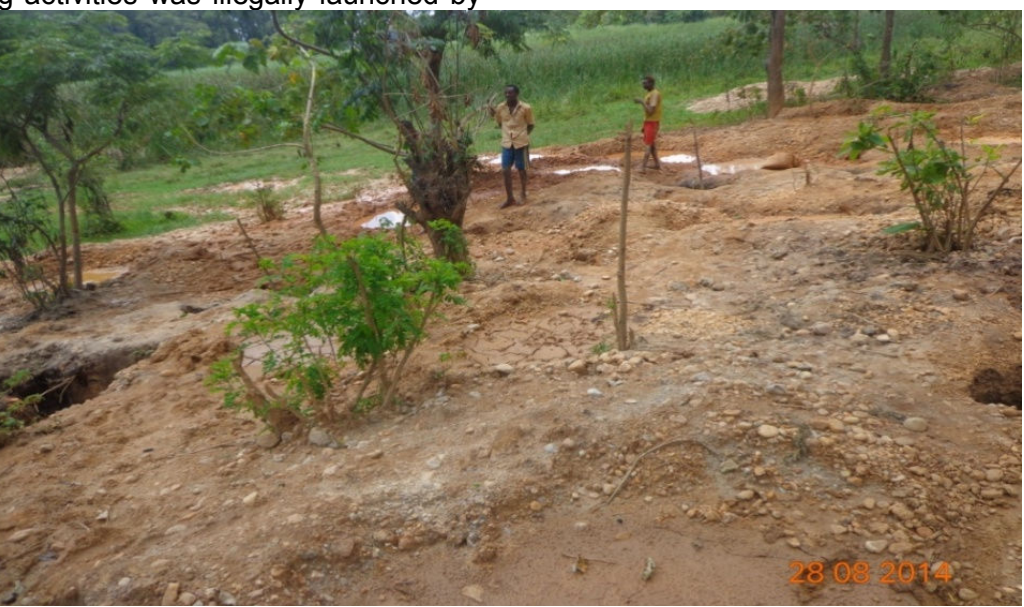

Figure 5: The degradation of the Rophi Megada wetlands by gold mining

Besides the above factors, the land use and land cover changes of the three wetland areas were assessed by ERDAS, 8.6 soft ware for further clarification of trend of changes of the wetlands (Figure 7 \& Figure 8 ).
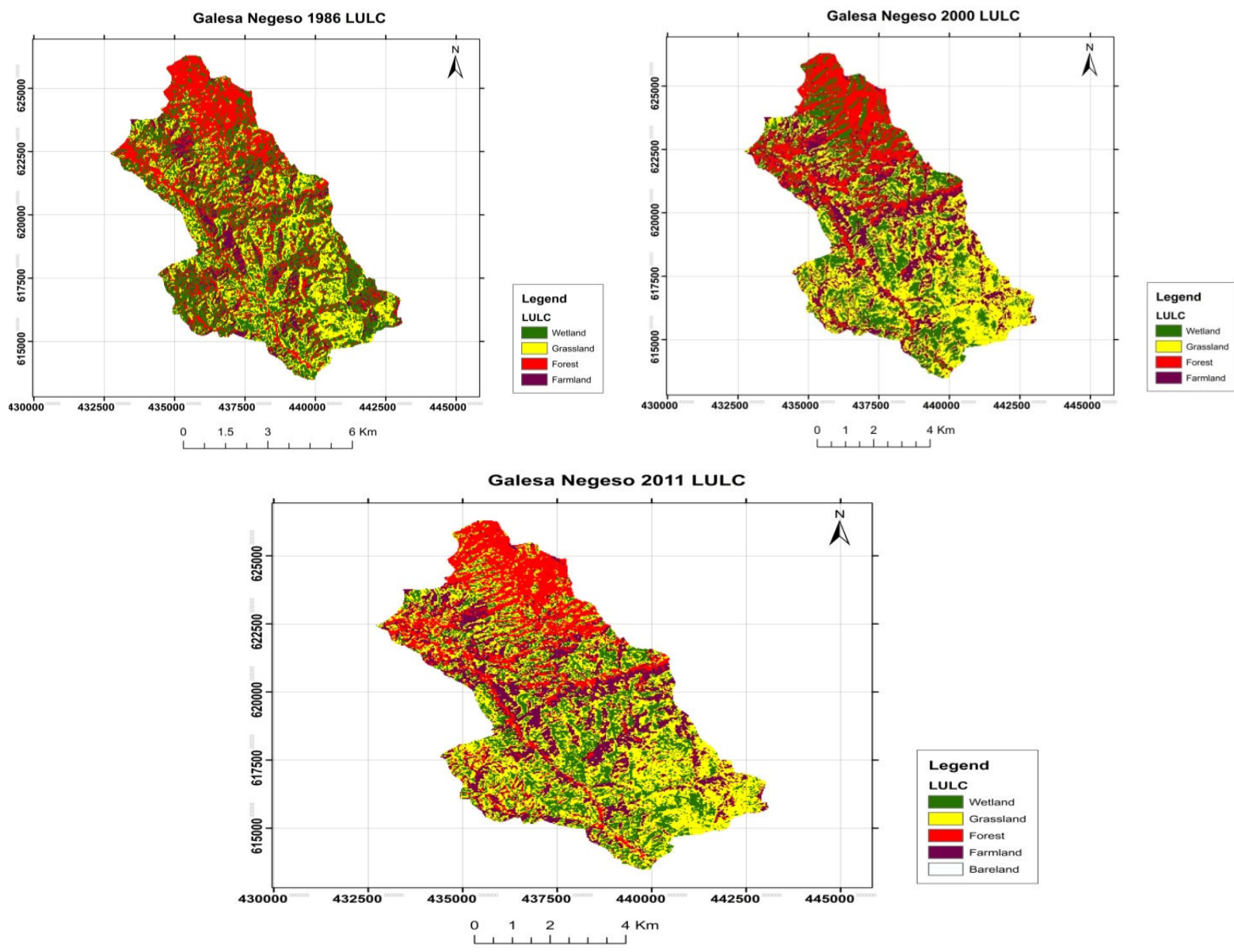

Source: Landsat TM 1986, LandsatETM+2000 and SPOT 2011

Figure 6. 1986, 2000 and 2006 maps of the Galessa Negesso wetlands 
Table 1: Galesa Negesso LULC

\begin{tabular}{|c|c|c|c|}
\hline \multirow{2}{*}{ LULC Type } & \multicolumn{3}{|c|}{ Year } \\
\hline & 1986 & 2000 & 2011 \\
\hline Wetland (ha) & 1707.36 & 1444.23 & 1296.98 \\
\hline Grass Land (ha) & 2497.31 & 2727.63 & 2818.42 \\
\hline Forest (ha) & 1648.49 & 1596.24 & 1481.41 \\
\hline Farmland (ha) & 439.46 & 524.52 & 683.02 \\
\hline Bare land (ha) & & & 12.79 \\
\hline Total & 6292.62 & 6292.62 & 6292.62 \\
\hline
\end{tabular}

Table 1 indicates that the Galesa Negesso wetland was reduced from 1707.36 ha to 1296.98 ha from 1986 to 2011 respectively.

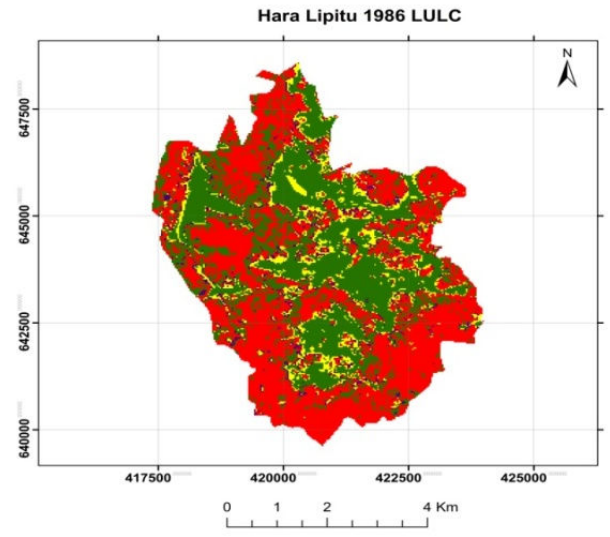

Table 2 indicates that the Hera Liphitu wetland was reduced from $\mathbf{7 2 5 . 3 3}$ ha to $\mathbf{4 4 4 . 1 1}$ ha from 1986 to 2011 respectively.
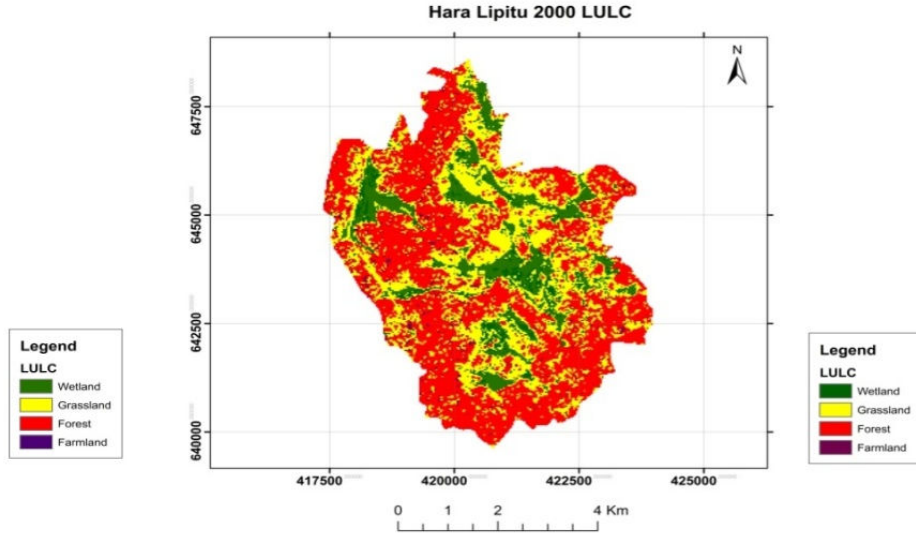

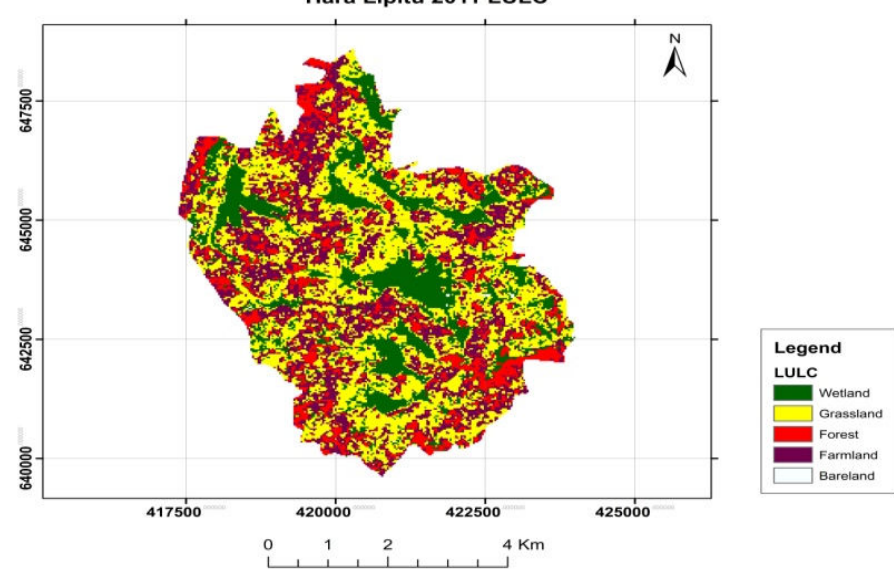

Source: Landsat TM 1986, LandsatETM+2000 and SPOT 2006

Figure 7: 1986, 2000 and 2006 maps of the Hera Liphitu wetlands

Table 2: Hera Liphitu LULC

\begin{tabular}{cccc}
\hline \multirow{2}{*}{ LULC Type } & \multicolumn{3}{c}{ Year } \\
\cline { 2 - 4 } & $\mathbf{1 9 8 6}$ & $\mathbf{2 0 0 0}$ & $\mathbf{2 0 1 1}$ \\
\hline Wetland(ha) & $\mathbf{7 2 5 . 3 3}$ & $\mathbf{5 9 6 . 5 2}$ & $\mathbf{4 4 4 . 1 1}$ \\
Grass Land(ha) & 914.37 & 1029.42 & 1201.37 \\
Forest(ha) & 1704.12 & 1672.65 & 1632.55 \\
Farmland (ha) & 52.33 & 97.56 & 115.17 \\
Bare land (ha) & 0 & & 2.95 \\
Total & $\mathbf{3 3 9 6 . 1 5}$ & $\mathbf{3 3 9 6 . 1 5}$ & $\mathbf{3 3 9 6 . 1 5}$ \\
\hline
\end{tabular}

Source: Satellite Image Analysis, 2014 

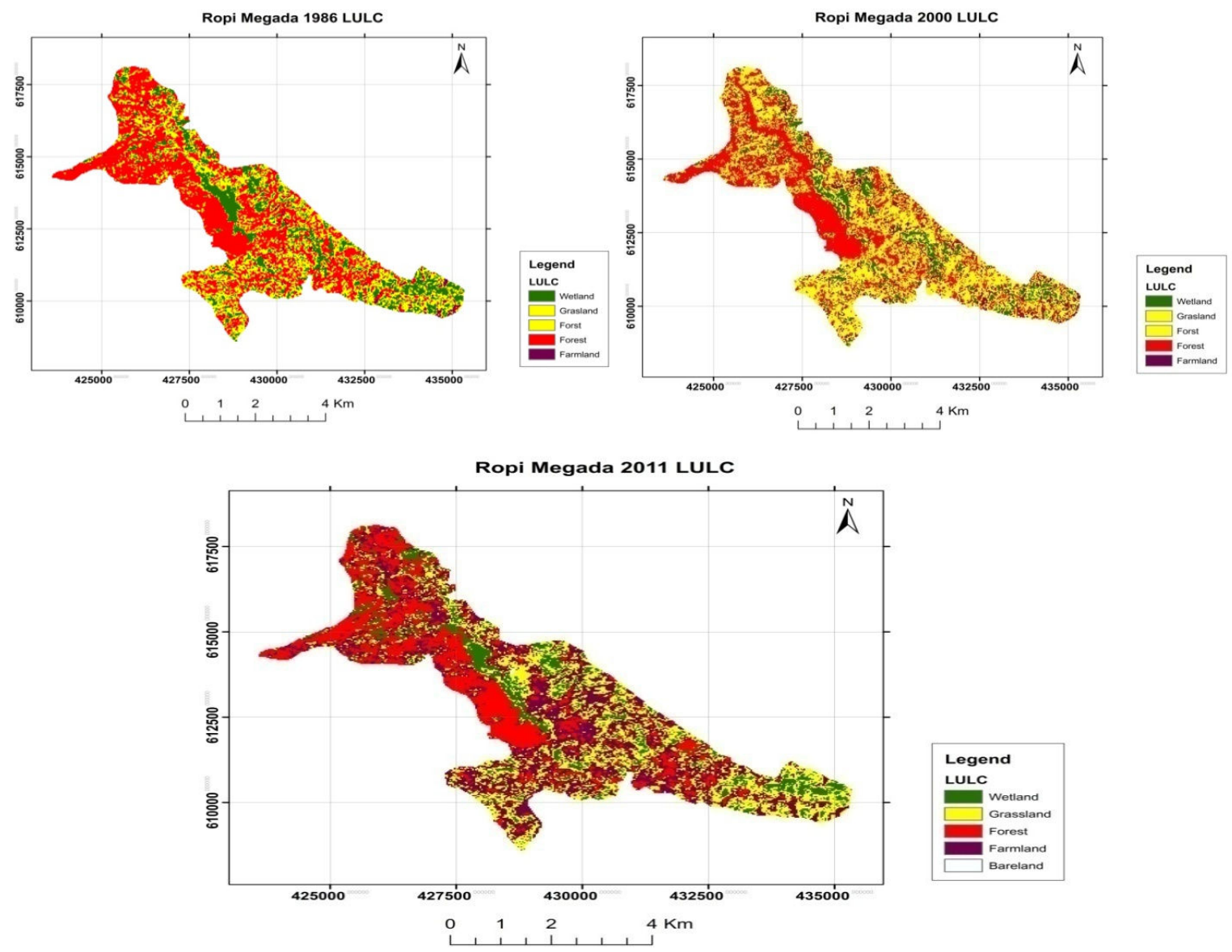

Source: Landsat TM 1986, LandsatETM+2000 and SPOT 2006

Figure 8: The 1986, 2000 and 2006 maps of the Rophi Megada wetlands

Table 3: Ropi Megada LULC

\begin{tabular}{|c|c|c|c|}
\hline \multirow{2}{*}{ LULC Type } & \multicolumn{3}{|c|}{ Year } \\
\hline & 1986 & 2000 & 2011 \\
\hline Wetland(ha) & 464.74 & 394.83 & 308.52 \\
\hline Grass Land(ha) & 872.04 & 1118.07 & 1180.37 \\
\hline Forest(ha) & 1739.81 & 1454.94 & 1133.05 \\
\hline Farmland (ha) & 12.39 & 121.14 & 459.25 \\
\hline Bare land (ha) & & & 7.79 \\
\hline Total & 88.98 & 3088.98 & 3088.98 \\
\hline
\end{tabular}

As it was indicated in Table 3,the Ropi Megada wetland was reduced from 464.74ha to 308.52ha from 1986 to 2011 respectively

The Impacts of Wetlands Degradation on the Local Socio-Economic Conditions

The loss of ecosystem services of wetlands can have both economic and environmental consequences (Marti, 2011). In the absence of the wetland, there would be no wetland products - the full value of products harvesting can therefore be attributed to household economic development (Emerton et al., 1997; Andeweg, 2006).

The overall result of wetland degradation processes, through their immediate and then their long-term impacts, is to contribute to the loss of precious wetland resources that will directly and indirectly contribute to the livelihoods of thousands of citizens. While there may be short-term gains in food production or other benefits from intensive wetland use and transformation, the long term effect is generally negative and the increased wetland-based benefits cannot be sustained. Clearly, wetland degradation can have a major implication for various aspects of livelihoods, especially in the dry season, such as domestic water supply, fish, grazing, and even crop production, and this has socio-economic implications (Forum for Environment, 2007).

In the same way, the information gathered from the communities particularly from elder groups informed that 


\section{Adugna Babu}

since the shrinkage of these wetlands the beneficiaries the ecosystems have been suffered due to the loss of different items that the communities use for some purposes. Some of the problems imposed up on the communities of study areas due to the degradation of these wetlands are scarcity of fresh water, scarcity of fodder for cattle especially during dry season, shortage of cultivation of some crops, lack of wetland plants "Cyprus Latifolius" or "cheffe" for traditional house construction, loss of some medicinal plants from these wetlands, loss of other items which can be sold to local market.

\section{Scarcity of Fresh Water}

Wetlands are an obvious source of water for domestic, agricultural (irrigation, livestock) or industrial use. Surface or near-surface water is a characteristic of many wetland types, such as lakes, rivers, mires and bogs, and is thus easily available for direct use. The loss of wetlands affects the livelihoods of wetland dependent communities in many ways (Barbier, 1997; Chin, 2006).

As it was said by the respondents, due to the shrinkage of the wetlands the people living surrounding these ecosystems face water problems mostly during the dry period of the year. This is because most parts of these wetlands are changed from permanent to temporary type. Temporary wetlands are wetlands associated rain fall, i.e. when rain fall comes their surface water increase and as rainfall stops the become dry. They loss water for drinking (for human and animal), for washing, and for other sanitation. Even during dry season the household particularity the women travel some distance toward some rivers for fetching water.

\section{Scarcity of Fodder}

The threat from overuse and unwise management of these resources might cause a significant damage to the wetlands themselves and to the ecology of their environs and might reach a larger area. Furthermore, the loss of wetlands and their resource will also directly affect those who are directly and indirectly dependent on them for their livelihood.

Wetlands are the main sources of fodder for cattle especially during dry season. The communities of the study area revealed that as a result of wetland loss from their surrounding area they experienced fodder scarcity even for some animals like calf and lactating cows (Mckee, 2007). The impacts from the current threats on wetlands resources in general have different negative outcomes particularly on loss of dry season grazing site which affects pastoral livelihoods.

\section{Shortage of Cultivation of Some Crops}

According to McKee (2007), insufficient attention is paid to the fact that wetlands are part of extensive socioeconomic and environmental systems. For instance, the characteristics of a wetland, especially its hydrological regime, can affect the ecology and therefore the agriculture in the areas surrounding it through the local groundwater table it supports. This can also affect local springs and domestic water supply.

According to the information gathered from the study areas beginning from the declining of these wetlands as the results of unprecedented anthropogenic activities the
Sci. Technol. Arts Res. J., April-June 2015, 4(2): 99-111

cultivation of some crops for the purposes of home consumption and selling are delayed.

\section{Loss of Some other Wetland Products}

According to Barbier, (1997), Wetlands provide vital supplies of timber for construction, fuelwood for cooking and heating, and other tree products such as medicines. However, if these resources are utilized unwisely, there is the probability to lose these products.

Deforestation and losses of vegetation within a wetland catchment area is the starting cause for an accumulation of silt within the wetland ecosystem. The accumulation of silt within the wetland usually leads to a complete change in the ecosystem, resulting in biodiversity alteration, in decreases in the water holding capacity of the wetland and in the worst case in the collapse of the wetland resources (Afework, 2004 cited in McKee, 2007)

The information given by some of respondents of the study area informed that since the degradation of these wetlands they experienced shortages of some products which are either consumed for some purposes or sold to local market areas for income generation.

In Rophi Megada wetland some plant species which the local communities use as medicine are disappeared and some edible plant species which are associated with wetlands are also under threat.

Some of the edible plants of Rophi Megada that are under threat included; Carissa spinarum L. (Apocynaceae), Syzygium guineense var. (Wild.) DC. (Myrtaceae), Dioscorea bulbifera L. (Dioscoreaceae), Olea europaea subsp. cuspidata (Wall. Ex G. Don) Cif., (Oleaceae), Capparis tomentosa Lam.( Capparidaceae), Teclea simplicifolia (Engl.) Verdoorn(Rutaceae), Ficus sur Forssk.( Moraceae), Physalis peruviana L.( Solanceae).

\section{The Impacts of Wetlands Degradation on Flora and Fauna Resources}

According to Mengistu (2008), losses of wetlands have resulted in greater flooding and erosion and reduced water quality, and have resulted in reduced populations of many plants and animals. In the same way in the three wetlands some indispensible species were disappeared and others are reduced in number due to degradation of these wetlands.

\section{Impacts of Wetlands Loss on Flora Resources}

The water-saturated environment of wetlands supports a unique group of plants called "hydrophytes". These plants are adapted to grow in waterlogged soils. The processes of loss and degradation reduce the ability of wetlands to support biodiversity (Ramsar Convention, 2002). In wetland ecosystem water is the primary factor controlling both the plant and animal life. It favours particular type of trees, shrubby species and associated herbs and grasses (IBC, 2012). According the informants , in these study areas, several vegetation diversity that are under threat include Ficus ovate, Vernonia auriculifera ,Teclea nobilis Del., Maesa lanceolata Forssk., Maytenus addat (Loes.), Erythrina brucei Schweinf., Acanthus eminens; Croton macrostachyus, Euphorbia ampliphylla, Cyprus latofolius, Cyprus manditi, Flacourtia indica, Ficus sur Forssk., Eriosema scioanum, Carissa spinarum, Syzygium guineense, Olea europaea subsp. Cuspidate, 


\section{Adugna Babu}

Cordia africana, Acacia abyssinica, Acacia albida; Lippia adoensis Hchest. ex Walp., Millettia ferruginia, Rubus steudneri, Senna petersiana. Due to the shrinkages of these wetlands the growth of these trees are delayed and those previously grown are under pressure of human population.

\section{Impacts of Wetlands Loss on Fauna Resources}

Wetland degradation is part of the wider environmental degradation process which has been going on in Ethiopia for many decades and has seen the loss of not only livelihood benefits, but also biodiversity and wildlife (Forum for Environment, 2007). Loss of wetlands has very specific impact upon particular plants and animals; it also has widespread impact on people and livelihoods through its effect on the hydrological system as well. According to Legesse, (2008); Wetlands of Ethiopia are prominent shelter of aquatic and terrestrial biodiversity. Endemic fishes, birds and other life forms depend on wetlands. The loss of these wetlands is devastating to several endemic species and particularly to wetland dependent species.

The animals found in wetlands include both those that depend on wetlands for essential parts of their life cycle such as breeding, feeding or sheltering sites and those that can live their whole lives only in wetlands. Members of the fish, amphibian, and reptile groups are all dependent on the habitat provided by wetlands. Numerous bird and mammal species make extensive use of the water and its adjacent shores. These species can be important to humans economically or as indicators of environmental health (Mengistu, 2008).

According to the elders of the communities of the study wetlands, some wild animals that were previously existed in these wetland areas were disappeared due to degradation of these wetland ecosystems. Some of these wild animals include duicker, aardvark, porcupine, bushback, Trign (Civettictis civetta), Rabbit, and pig. As a result of destruction of habitats such as marshes and swampy forests, some wild animals that reside in them are subject to extinction (Choowaew, 2007).

Water birds categorized as wetland 'specialists' nest, feed and roost in wetlands and thus are dependent on aquatic habitats, to the extent that they cannot survive without them (Mengistu, 2008).

Furthermore, according to the information gathered from elders of the study wetlands, some bird species of the wetlands are also under threat due to the destruction of wetlands. Some of the species of the birds which are under threat include Cattle Egret, Great White Egret, Hadada Ibis, Egyptian Goose, Egyptian Vulture, Abyssinian Ground Hornbill, and Laughing Dove. According the elder respondents, Cattle Egret and Great White Egret; the bird species associated with cattle are now a day not present in these study wetlands.

\section{CONCLUSIONS}

Though there are many wetlands in Bulehora woreda, these resources are under threat resulting from unplanned settlement, conversion to agricultural practices, eucalyptus plantation, overgrazing, deforestation, and gold extraction (Rophi Megada Wetland). This is because from regional up to grass root level the communities have no awareness to conserve and manage these ecosystems since there were no special training services given them
Sci. Technol. Arts Res. J., April-June 2015, 4(2): 99-111

in order to attain conservation strategies. According to the respondents, as a result of the loss of these resources many local communities lost some important benefits which are expected from these wetlands. Therefore, the informants experienced many problems such as scarcity of fresh water, loss of wetland grasses which are used as fodder during dry season and traditional roofing, loss of some medicinal plants, edible fruits and others. Besides this, biodiversity, particularly the fauna and flora resources are also affected as a result of loss of wetlands. According to the local elders, beginning from the shrinkages of these wetlands, some plants, animals as well as are some species of birds are disappeared.

\section{Conflict of Interest}

Author declared no conflict of Interest.

\section{REFERENCES}

Afework, H., Wood and Abbot (2000). Sustainable Wetland Management in Illubabor Zone, South-west Ethiopia; Appropriate techniques for sustainable wetland management: University of Huddersfield. UK.

Afework, H. (2008). Researching on wetlands on southwestern Ethiopia: The Experience of Ethiopian wetlands Research Programme. An overview in Proceedings of the wetland Awareness creation and activity identification workshop in Amhara Regional National State, Bahir Dar.

Agricultural Office of the Bule Hora Woreda (AOBHW), (2013). The annual report on production of crops

Andeweg, K. (2006). Central Issues in decentralized wetland management: Comparative Case study in Kumi and Mukono district, Uganda; Msc thesis, Wageningen University.

Barbier, E.B., Acreman, M. and Knowler, D (1997). Economic valuation of wetlands :A guide for policy makers and planners; Ramsar Convention Bureau Gland, Switzerland

Barbier., Acreman and Knowler (1997). Economic Valuation of wetlands :Ramsar Convention Bureau; Gland, Switzerland.

Berhanu, T. (2003). Environmental impact assessment and the wise use of wetlands Environmental Protection Authority, Addis Ababa; An overview in Proceedings of a Seminar on the resources and status of Ethiopia's wetlands, (Abebe, Y.D. and Geheb, K. (eds), IUCN.

Choowaew, S. (2007). Wetland functions and values; Programme Director (Natural Resource Management); Faculty of Environment and Resource Studies, Mahidol University Salaya, Nakhonpathom 73170, Thailand

Chin, D.A. (2006). Water -Quality Engineering in Natural Systems. University of Miami, Coral Gables, Florida; Wiley Interscience.

Dereje, A. (2008). The Relevance of Wetlands to Attain Millennium Development Goals (MDGs) and Objectives of the Rio Conventions in Ethiopia; Federal Environmental Protection Authority, Fisheries Biodiversity Specialist; An overview in Proceedings of the National Stakeholders' Workshop on Creating National Commitment for Wetland Policy and Strategy Development in Ethiopia; Shimeles Sima and Geremew G/Selassie (eds); EWNRA, A.A, Ethiopia.

Dixon, A.B. and Wood, A.P. (2007). Sustainable Wetland Management for food security and rural livelihoods in South -West Ethiopia: The interaction of local knowledge and institutions, government policies and Globalization The University of Huddersfield and wetland Action, UK 


\section{Adugna Babu}

Dixon, A.B. and Wood, A.P (2003). Local Institutions for Wetland Management in Ethiopia: Sustainability and State Intervention; Centre for Wetlands, Environment and Livelihoods, University of Huddersfield, Huddersfield, UK.

Emerson (1998). The present economic value of Nakivubo urban wetland, Uganda; The world conservation union, Eastern Africa Regional office, Nairobi, Kenya.

Emerton, L. (1998). Economic Tools for Valuing Wetland in Eastern Africa; The world Conservation Union, Biodiversity Economics in Eastern Africa.

Ethio-Wetlands and Natural Resource Association (EWNRA), (2003). Wetland Water Supplies: Assessing the Impact of Human Disturbance of wetlands and Identifying Management Solutions in Metu Woreda, Illubabor Zone, Ethiopia, and Final report for SIDA.

Fischer, G. (2002). Land and water use of wetlands in Africa: Economic value of African wetlands; International Institute for Applied Systems Analysis, Laxenburg, Austria.

Forum for Environment (2007). Proceedings of the Public Meetings on Harnessing the Water Resources of Ethiopia for Sustainable Development in the New Ethiopian Millennium Global Water Partnership Eastern Africa (Ethiopia Country Water Partnership, ECWP) Water Aid : Ethio Wetlands and Natural Resources Association (EWNRA): Abebe Ameha(eds): Addis Ababa

IBC (2012). Wetland Ecosystem: Addis Ababa; Ethiopia.

Jones. M.J. (1997). Conservation Strategy for big Wood River Basin Wetlands: Idaho Department of Fish and Game; Natural Resource Policy Bureau

Kusler, J. (2003). Wetlands and Watershed Management. Institute for Wetland Science and Public policy of the Association State of Wetland Managers; A Guide for local Governments.

Lambert, A. (2003) Economic valuation of wetlands: an important component of wetland management strategies at the River Basin scale, Ramsar convention.

Legesse, T. (2008). The Roles of Wetlands in Food Security and Poverty Reduction in Ethiopia: An overview in Proceedings of the National Stakeholders' Workshop on Creating National Commitment for Wetland Policy and Strategy Development in Ethiopia Shimeles Sima and Geremew G/Selassie (eds); EWNRA, Addis Ababa; Ethiopia.

Lemlem, S. (2003). Biodiversity potentials and threats to the southern Rift ValleyLakes of Ethiopia. Institute of Biodiversity Conservation and Research. An overview in proceedings of a seminar on the resources and Status of Ethiopia's wetlands, Abebe, Y. D. and Geheb, K (eds); IUCN.

Leykun, A. (2003). The distribution and status of Ethiopian wetlands: An Overview in Wetlands of Ethiopia, An overview proceedings of a seminar on the resources and status of Ethiopia's wetlands, Abebe, Y.D. and Geheb, K. (eds), IUCN.

Marti, A. (2011). Wetlands: A Review; With Three Case Studies: The People's Republic of China, The United
Sci. Technol. Arts Res. J., April-June 2015, 4(2): 99-111

States of America, and Ethiopia: International Resource Management

Mckee, J. (2007). Ethiopia Country Environmental Profile; EC Delegation, Addis Ababa.

Mellese, D. (2008). Policies, Laws and Strategic Documents in Protecting Wetlands in Ethiopia and the Need to Ratify the Ramsar Convention; An overview in Proceedings of the National Stakeholders' Workshop on Creating National Commitment for Wetland Policy and Strategy Development in Ethiopia Shimeles Sima and Geremew G/Selassie(eds);EWNRA,A.A; Ethiopia.

Mengistu, W. (2008). The role of Wetlands in Biodiversity Conservation and Management in Ethiopia: a case study of Berga Floodplain. An overview in Proceedings of the National Stakeholders' Workshop on Creating National Commitment for Wetland Policy and Strategy Development in Ethiopia Shimeles Sima and Geremew G/Selassie(eds); EWNRA, A.A; Ethiopia.

Millennium Ecosystem Assessment (MEA) (2005). Ecosystems and Human Well-being: Wetlands and Water Synthesis. World Resources Institute, Washington, DC.

Morton, R.A., Tiling, G., and Ferina, N.F. (2003). Causes of hot-spot wetland loss in the Mississippi Delta plain; enter for Coastal and Watershed Studies: Petersburg, Florida.

Oyugi, D.O. and lyango, L. (2007).Wetlands and Poverty Reduction Project; Lecture Notes /Work book Module 1: Wetlands and Integrated Water Resources Management. Wetlands International, Wetlands and Poverty reduction project, Anglophone, regional practitioners training course, Entebbe, Uganda

Ramsar Convention (2002). A Global Overview of Wetland Loss and Degradation: Wetlands International Conference, Australia Ramsar Convention Secretariat, 2006: The Ramsar Convention Manual: a guide to the Convention on Wetlands (Ramsar, Iran, 1971), $4^{\text {th }}$ ed. Ramsar Convention Secretariat, Gland, Switzerland.

Ramsar, (2007). River Basin management: Ramsar handbooks for the wise use of wetlands, third edition, Department of state and U.S; Fish and wildlife service.

Shewaye, D. (2008). Wetlands and Management Aspects in Ethiopia: Situation Analysis; AN overview in Proceedings of the National Stakeholders' Workshop on Creating National Commitment for Wetland Policy and Strategy Development in Ethiopia Shimeles Sima and Geremew G/Selassie(eds);EWNRA,A.A ; Ethiopia

Tejuoso, O.J. (2006). Wetland uses/dynamics for agricultural purposes and its health implications in lower Ogun river basin,Lagos, Nigeria, International Development Research Centre.

Yilma, D. and Geheb (2003). Wetlands of Ethiopia; proceeding $\mathrm{s}$ of a seminar on the resources and status of Ethiopia's wetlands; IUCN.

Zerihun, D. (2003). Challenges and opportunities of Ethiopian wetlands: the case of Lake Awassa and its feeders, Awassa University, Awassa. An overview in Proceedings of a Seminar on the resources and status of Ethiopia's wetlands, Abebe, Y. D. and Geheb, K. (eds), IUCN. 